\title{
Physico-chemical interactions at the concrete-bitumen interface of nuclear waste repositories
}

\author{
A. Bertron ${ }^{1,}$,, H. Ranaivomanana ${ }^{1}$, N. Jacquemet ${ }^{1}$, B. Erable $^{2}$, C. Sablayrolles ${ }^{3,4}$, G. Escadeillas ${ }^{1}$ \\ and A. Albrecht ${ }^{5}$ \\ ${ }^{1}$ Université de Toulouse; UPS, INSA; LMDC (Laboratoire Matériaux et Durabilité des \\ Constructions); 135, avenue de Rangueil; F-31 077 Toulouse Cedex 04; France \\ ${ }^{2}$ Université de Toulouse; INPT, UPS ; CNRS; Laboratoire de Génie Chimique; 4, Allée Emile \\ Monso, F-31030 Toulouse, France \\ ${ }^{3}$ Université de Toulouse; INP; LCA (Laboratoire de Chimie Agro-Industrielle); ENSIACET, 4 allée \\ Emile Monso, BP 44 362, 31432 Toulouse Cedex 4, France \\ ${ }^{4}$ INRA; LCA (Laboratoire de Chimie Agro-Industrielle), F-31029 Toulouse, France \\ ${ }^{5}$ Andra, 1-7, rue Jean-Monnet - 92298 Châtenay-Malabry, France
}

\begin{abstract}
This study investigates the fate of nitrate and organic acids at the bitumenconcrete-steel interface within a repository storage cell for long-lived, intermediatelevel, radioactive wastes. The interface was simulated by a multiphase system in which cementitious matrices (CEM V-paste specimens) were exposed to bitumen model leachates consisting of nitrates and acetic acid with and without oxalic acid, chemical compounds likely to be released by bitumen. Leaching experiments were conducted with daily renewal of the solutions in order to accelerate reactions. C-steel chips, simulating the presence of steel in the repository, were added in the systems for some experiments. The concentrations of anions (acetate, oxalate, nitrate, and nitrite) and cations (calcium, potassium, ammonium) and the $\mathrm{pH}$ were monitored over time. Mineralogical changes of the cementitious matrices were analysed by XRD. The results confirmed the stability of nitrates in the absence of steel, whereas, reduction of nitrates was observed in the presence of steel (production of $\mathrm{NH}_{4}{ }^{+}$). The action of acetic acid on the cementitious matrix was similar to that of ordinary leaching; no specific interaction was detected between acetate and cementitious cations. The reaction of oxalic acid with the cementitious phases led to the precipitation of calcium oxalate salts in the outer layer of the matrix. The concentration of oxalate was reduced by $65 \%$ inside the leaching medium.
\end{abstract}

\section{Introduction}

A significant fraction of long-lived, intermediate-level, radioactive wastes (bituminous wastes) consist of a mixture of inorganic salts immobilized in a bitumen matrix. They are poured in cylindrical steel containers called primary packages. Depending on the disposal concept, these

\footnotetext{
a e-mail: bertron@insa-toulouse.fr
}

This is an Open Access article distributed under the terms of the Creative Commons Attribution License 2.0, which permits unrestricted use, distribution, and reproduction in any medium, provided the original work is properly cited. 
containers are grouped into cuboid reinforced concrete overpacks. These secondary packages are then placed inside waste cells built at a depth of 450 to $550 \mathrm{~m}$ within a Callovo-Oxfordian clay rock formation, using significant amounts of additional concrete (i.e. lining, shotcrete) [1-3].

After closure of the cells, water resaturation that probably fills the waste cells from the bottom up (bathtub effect), reaching near-saturation within a few thousand years, should enhance the release of chemical species. Among other compounds probably released into the interstitial aqueous medium are soluble salts (notably nitrates) and organic matter such as organic acids, phenols, etc. contained within the bituminous matrix [4], together with gas (mostly $\mathrm{H}_{2}$ ) produced via radiolysis of organic matter and/or anaerobic steel corrosion (black and stainless steel present in primary containers and concrete reinforcement).

The presence of nitrates in the vicinity of waste packages may result in oxidising conditions favourable to the mobility of a series of radionuclides [5]. However, in the overall reducing conditions prevailing in the cell, different redox reactions are likely to occur, including nitrate reduction driving the system back to a reducing environment favourable to safe storage. Reduction of nitrate $\left(\mathrm{NO}_{3}^{-}\right)$may occur (i) from abiotic processes, with iron from the steel and/or $\mathrm{H}_{2}$ acting as electron donors, and surface catalysis provided by the different types of steel and corrosion products present in the storage cell, and/or (ii) from biological catalysis through bacterial activity (biotic reaction). The reactions may lead to the formation of nitrite $\left(\mathrm{NO}_{2}^{-}\right)$, gaseous nitrogen $\left(\mathrm{N}_{2}\right)$ and/or ammonium $\left(\mathrm{NH}_{4}^{+}\right)$, depending on a variety of parameters not yet well understood, particularly in concrete-dominated systems [6-11]. Both types of nitrate reactions (abiotic and biotic) involve electron donors and numerous inorganic and organic candidates are available in the storage cell or in the host rock (organic acids, $\mathrm{H}_{2}$, zero-valent metals...) [5]. All reactions occur in an environment influenced by the alkaline conditions imposed by the concrete phases. The overall project, of which this paper is a part, aims to investigate the reduction of nitrates within a system comparable to a "real" waste-cell where bacterial activity is likely to occur (denitrifying alkaliphilic bacteria) and notably to determine the phenomenology and kinetics of reactions and the role of the electron donor (i.e. organic acids released by bitumen, such as acetic or oxalic acids) in the reactions [9]. The investigation of bacterial denitrifying activity is the aim of the paper by Alquier et al. [12], proposed in this conference.

However, previous studies have shown that strong interactions occur between cementitious materials and organic acids [13-17]. These reactions could modify not only the bioavailability of organic matter - and thus influence the reactivity of nitrates - but also the composition of the concrete and its ability to buffer the chemical system (i.e. $\mathrm{pH}$ ).

The aim of the present paper is, under abiotic conditions and without bacteria, to investigate (i) the interactions of organic acids with the cementitious matrix and (ii) the reactivity of nitrates in the presence/absence of carbon steel.

Reactions and the related equilibria of multiphase systems representative of the bitumenconcrete-steel interface were investigated. In a first set of experiments, CEM V paste specimens were immersed in solutions made of acetic and/or oxalic acids and nitrates that simulated bitumen model leachates. In a second set of experiments, C-steel chips and bitumen pieces were added to the system. Changes in the cement pastes and liquid phase compositions were investigated.

\section{Materials and methods}

\subsection{Materials}

\subsubsection{Cement pastes}

CEM V/A 42.5 (S-V) N CE PM-ES-CP1 cement pastes (Airvault Calcia factory) were made with a water/cement ratio of 0.40 . They were cast in cylindrical plastic moulds $50 \mathrm{~mm}$ high and $27 \mathrm{~mm}$ in diameter without demoulding oil and were vibrated to evacuate air voids. The specimens were taken 
out of their moulds 24 hours after pouring and stored in water at $20^{\circ} \mathrm{C}$ for 28 days. They were then subjected to the leaching tests described below. In parallel, some control specimens were kept in water at $20^{\circ} \mathrm{C}$.

\subsubsection{Solid bitumen}

ASALT 35-50 bitumen was used in this study. It was hand-shaped in the form of small cylinders (height $=2 \mathrm{~cm}$, diameter $=1 \mathrm{~cm}$ ) prior to the tests.

\subsubsection{Steel}

Steel chips were collected from the machining of C40 carbon steel ( $0.4 \%$ carbon), essentially composed of metallic iron $\left(\mathrm{Fe}^{0}\right)$.

\subsubsection{Bitumen leachates solutions}

Uncertainties remain on the release of organic and inorganic matter by bitumen-salt mixtures. Experimental studies have shown that the degradation of bitumen gives rise to the release of organic matter (naphthalene, alcohols, linear carboxylic acids, aromatics and glycols) and salts $\left(\mathrm{NaNO}_{3}\right.$, $\mathrm{Na}_{2} \mathrm{SO}_{4}$, etc.) [4,18-23]. On the basis of this literature data, leaching of bitumen was simulated by aqueous solutions made of organic acids (acetic and oxalic acids) and nitrates. Linear carboxylic acids were considered (i) since they are easily assimilated by bacteria and (ii) because of their probable strong interactions with cement phases. Calcium salts of acetic acids being highly soluble in water [24], it is likely that both acids have similar effects on the cementitious matrix [25]. In contrast, calcium oxalate salts are only slightly soluble in water [26,27] and are thus likely to be produced during the attack of cementitious matrix by oxalic acid.

Three types of model leachate solutions were considered (Table 1). The first type was made of acetic acid $(0.50 \mathrm{mM}-30 \mathrm{mg} / \mathrm{L})$ and sodium nitrate $(32.3 \mathrm{mM})$. The initial $\mathrm{pH}$ of this solution, noted as $\mathrm{N}+\mathrm{OA} 1$, was 4.0 . The second type was a mix of acetic acid $(0.33 \mathrm{mM})$, oxalic acid $(0.17 \mathrm{mM})$ (same total concentration of acids of $0.50 \mathrm{mM}$ ) and sodium nitrate $(32.3 \mathrm{mM})$. The $\mathrm{pH}$ of this solution, noted as $\mathrm{N}+\mathrm{OA} 2$, was 3.6. The third type of solution, noted $\mathrm{N}$, was made of sodium nitrate alone $(32.3 \mathrm{mM})$, with initial $\mathrm{pH}$ of 7.0 . The nitrate concentration $(32.3 \mathrm{mM})$ was only an estimate of the likely concentration in a waste cell (results of coupled chemical and transfer modelling) [28,29].

Table 1. Compositions of bitumen model leachates.

\begin{tabular}{|c|c|c|c|c|c|c|c|}
\hline \multirow{3}{*}{ Solutions } & \multicolumn{6}{|c|}{ Concentration } & \multirow[t]{3}{*}{ pH } \\
\hline & \multicolumn{2}{|c|}{ Acetic acid } & \multicolumn{2}{|c|}{ Oxalic acid } & \multicolumn{2}{|c|}{ Nitrate $\mathrm{NO}_{3}^{-}$} & \\
\hline & $\mathrm{mg} / \mathrm{L}$ & $\mathbf{m M}$ & $\mathrm{mg} / \mathrm{L}$ & $\mathbf{m M}$ & $\mathrm{mg} / \mathrm{L}$ & $\mathbf{m M}$ & \\
\hline $\mathrm{N}+\mathrm{OA} 1$ & 30 & 0.50 & - & - & 2000 & 32.3 & 4.0 \\
\hline $\mathrm{N}+\mathrm{OA} 2$ & 20 & 0.33 & 15 & 0.17 & 2000 & 32.3 & 3.6 \\
\hline $\mathrm{N}$ & - & - & - & - & 2000 & 32.3 & 7.0 \\
\hline
\end{tabular}

\subsection{Experimental set-up and process}

The experimental device comprised a reactor, filled with $1 \mathrm{~L}$ of nitrate/organic acid solution $(\mathrm{N}+\mathrm{OA} 1, \mathrm{~N}+\mathrm{OA} 2$ or $\mathrm{N}$, Table 1) and equipped with an outlet for solution sampling, a gas inlet with check valve (used for $\mathrm{N}_{2}$ bubbling to impose anoxic conditions inside the reactor similar to those that will prevail inside a repository cell), a gastight tap for $\mathrm{pH}$ and redox (reference electrode $\mathrm{Ag} / \mathrm{AgCl}$, reference potential $\mathrm{E}=199 \mathrm{mV}$ ) probes and a hermetically closed lid fitted with a gas vent.

The $\mathrm{pH}$ probe was connected to a data acquisition system (Consort, D230 Data Acquisition System, v1.1.13). The solution in the reactor was continuously stirred using a magnetic barrel. The cement paste specimen was suspended in the solution by a PTFE thread. The experimental device was kept in an air-conditioned room $\left(20^{\circ} \mathrm{C}\right)$ during the whole experiment. 
In a first series of experiments, a cement paste cylinder was immersed in $\mathrm{N}+\mathrm{AO} 1$ or $\mathrm{N}+\mathrm{AO} 2$ solution. The solid/liquid volume ratio was about $3 \%$. The solid area/liquid volume ratio was about $0.054 \mathrm{~cm}^{-1}$. N+OA1 (acetic acid $0.5 \mathrm{mM}$; $\mathrm{NO}_{3}{ }^{-} 32.23 \mathrm{mM}$ ) and $\mathrm{N}+\mathrm{OA} 2$ (acetic $0.33 \mathrm{mM}$ and oxalic $0.17 \mathrm{mM}$ acids; $\mathrm{NO}_{3}{ }^{-} 32.23 \mathrm{mM}$ ) solutions were renewed daily for 5 days. During the first day of exposure, the solution was sampled 4 times $(20-25 \mathrm{~mL}$ each sample). The solid/liquid ratio changed very little. On days 2 to 5 , a liquid sample was taken from the solution just before renewal. Concentrations of $\mathrm{Ca}, \mathrm{K}$, acetate, oxalate, nitrate and nitrite were measured on each sample.

In a second series of experiments, a cement paste cylinder (solid/liquid ratio 3\%, solid area/liquid volume ratio $0.054 \mathrm{~cm}^{-1}$ ) was immersed in $\mathrm{N}$ solution (nitrate $32.23 \mathrm{mM}$ ) together with bitumen (solid/liquid ratio $3 \%$, solid area/liquid volume ratio $\left.0.158 \mathrm{~cm}^{-1}\right)$ and steel chips $(7 \mathrm{~g} / \mathrm{L})$. The solution was not renewed during the 7-day-experiment. Concentrations of $\mathrm{Ca}, \mathrm{K}$, acetate and oxalate (to identify the possible release of these acids by the bitumen), nitrate, nitrite and ammonium were measured at 1, 2 and 7 days.

\subsection{Analytical methods}

\subsubsection{Methods for determining ion concentrations of solutions}

Concentrations of anions (acetate, oxalate, nitrate and nitrite) and of cations (calcium, potassium and ammonium) were measured by High Performance Ion Chromatography (HPIC) coupled to a conductimetric detector fitted with chemical suppressor (Dionex ICS-2000 and ICS-3000). The analytical conditions are given in $[9,30]$.

\subsubsection{Mineralogical analyses of cementitious specimens}

To explore the mineralogical changes, cement paste samples were analysed by X-Ray Diffraction (Siemens D5000; copper cathode; anode voltage $40 \mathrm{kV}$; current strength $30 \mathrm{~mA}$ ) after the leaching tests. The measurements were performed according to the distance inwards from the plane cylinder surface in contact with the solutions.

\section{Results and discussion}

\subsection{Cement paste-organic acids interactions}

In this section, the results of the experiments of CEM V pastes immersion in $\mathrm{N}+\mathrm{OA} 1$ and $\mathrm{N}+\mathrm{OA} 2$ solutions are presented and discussed.

\subsubsection{Macroscopic observations of cementitious specimens}

The cementitious matrix, initially grey, had turned to a yellowish colour at the end of the leaching experiments in $\mathrm{N}+\mathrm{OA} 1$ and $\mathrm{N}+\mathrm{OA} 2$ ( 5 days of immersion). This is characteristic of the leaching of a cementitious matrix by acidic solutions where Fe(III) of hydrated and or/anhydrous phases precipitates in the form of orangey-coloured iron hydroxide. The outer layer of leached CEM I and CEM V pastes is enriched in iron (relative enrichment) [15,31,32].

\subsubsection{Composition and $\mathrm{pH}$ of the test solutions}

Concentrations of $\mathrm{K}^{+}$and $\mathrm{Ca}^{2+}$ of $\mathrm{N}+\mathrm{OA} 2$ (acetic+oxalic acids) solutions in cement paste immersion tests are shown versus time in Fig. 1. Concentrations of $\mathrm{OH}^{-}$ions, calculated from continuous measurement of $\mathrm{pH}$ are also represented. Concentrations of nitrate, nitrite, acetate and oxalate of $\mathrm{N}+\mathrm{OA} 1$ and $\mathrm{N}+\mathrm{OA} 2$ solutions are given in Table 2. 


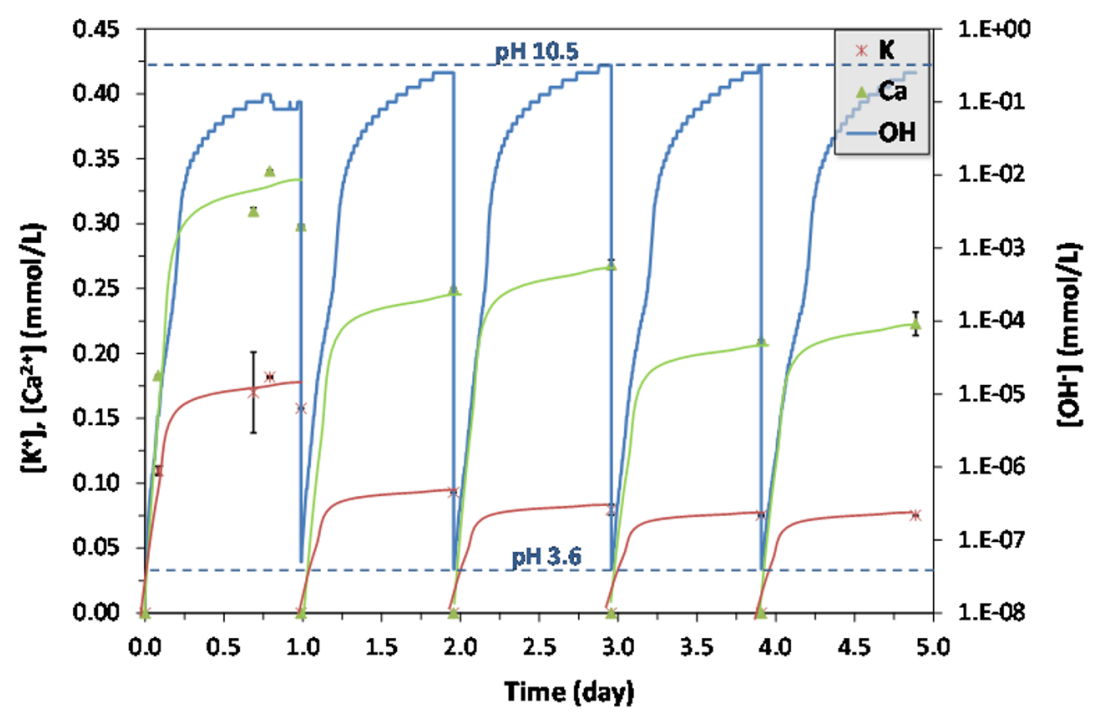

Fig. 1. Concentrations of $\mathrm{K}^{+}, \mathrm{Ca}^{2+}$ and $\mathrm{OH}^{-}$in $\mathrm{N}+\mathrm{OA} 2$ (acetic $0.33 \mathrm{mM} /$ oxalic $0.17 \mathrm{mM}$ acids; nitrate $32.3 \mathrm{mM}$ ) leaching solution. The solution was renewed daily. Solid area/liquid volume $\approx 50 \mathrm{~cm}^{2} / \mathrm{L}$. Concentration of $\mathrm{OH}^{-}$ was calculated from the $\mathrm{pH}$ values. For days 2 to 5 , variations of $\mathrm{K}$ and $\mathrm{Ca}$ concentrations are based on the final concentration and an evolution similar to day 1 .

Table 2. Evolution of concentrations $(\mathrm{mmol} / \mathrm{L})$ of anions in $\mathrm{N}+\mathrm{OA} 1$ and $\mathrm{N}+\mathrm{AO} 2$ solutions with time of cement paste immersion. Solution renewed daily. < DL: lower than the detection limit.

\begin{tabular}{|l|l|l|l|l|l|l|l|}
\hline \multirow{2}{*}{$\begin{array}{l}\text { Time } \\
(\text { day) }\end{array}$} & $\mathbf{N}+\mathbf{O A 1}$ solution & {$\left[\mathbf{N} \mathbf{O}_{\mathbf{3}}{ }^{-}\right]$} & {$\left[\mathbf{N O}_{\mathbf{2}}{ }^{-}\right]$} & {$[\mathbf{A c}]$} & {$[\mathbf{O x}]$} & {$\left[\mathbf{N O}_{\mathbf{3}}{ }^{-}\right]$} & {$\left[\mathbf{N O}_{\mathbf{2}}{ }^{-}\right]$} \\
\hline 0.00 & 0.57 & 31.64 & $<\mathrm{DL}$ & 0.37 & 0.17 & 31.83 & $<\mathrm{DL}$ \\
\hline 0.08 & 0.53 & 31.87 & $<\mathrm{DL}$ & 0.30 & 0.05 & 32.05 & $<\mathrm{DL}$ \\
\hline 0.67 & 0.62 & 31.39 & $<\mathrm{DL}$ & 0.26 & 0.07 & 31.73 & $<\mathrm{DL}$ \\
\hline 0.79 & 0.60 & 31.66 & $<\mathrm{DL}$ & 0.34 & 0.07 & 31.73 & $<\mathrm{DL}$ \\
\hline 1.00 & 0.61 & 31.62 & $<\mathrm{DL}$ & 0.34 & 0.06 & 31.79 & $<\mathrm{DL}$ \\
\hline 2.04 & 0.55 & 31.81 & $<\mathrm{DL}$ & 0.32 & 0.05 & 31.68 & $<\mathrm{DL}$ \\
\hline 3.04 & 0.52 & 31.71 & $<\mathrm{DL}$ & 0.28 & 0.06 & 31.90 & $<\mathrm{DL}$ \\
\hline 3.99 & 0.47 & 31.71 & $<\mathrm{DL}$ & 0.31 & 0.05 & 31.68 & $<\mathrm{DL}$ \\
\hline 4.97 & 0.56 & 31.64 & $<\mathrm{DL}$ & 0.30 & 0.05 & 31.79 & $<\mathrm{DL}$ \\
\hline
\end{tabular}

The variations of $\mathrm{pH}$ were similar for the five 24-h cycles: from the initial values of 4.0 for $\mathrm{N}+\mathrm{OA} 1$ (not shown) and 3.6 for $\mathrm{N}+\mathrm{OA} 2$ (Fig. 1), $\mathrm{pH}$ increased rapidly during the first 6 hours of leaching, to reach about 9.5 , then increased slowly to reach 10.6 in N+OA1 and 10.5 in $\mathrm{N}+\mathrm{OA} 2$ after 24 hours. Longer reaction times would allow $\mathrm{pH}$ to increase even further [9]. Alkaline conditions were thus very rapidly imposed in the leaching medium. The increase in $\mathrm{pH}$ was mostly due to the release of hydroxide ions by the dissolving cement paste matrix.

Concentrations of $\mathrm{K}^{+}$and $\mathrm{Ca}^{2+}$ varied the same way. During the first leaching cycle, variations followed those of $\mathrm{pH}$ and concentrations reached $\left[\mathrm{Ca}^{2+}\right] \approx 0.25 \mathrm{mmol} / \mathrm{L}$ and $\left[\mathrm{K}^{+}\right] \approx 0.15 \mathrm{mmol} / \mathrm{L}$ in $\mathrm{N}+\mathrm{OA} 1$ and $\left[\mathrm{Ca}^{2+}\right] \approx 0.33 \mathrm{mmol} / \mathrm{L}$ and $\left[\mathrm{K}^{+}\right] \approx 0.17 \mathrm{mmol} / \mathrm{L}$ in $\mathrm{N}+\mathrm{OA} 2$. For leaching days 2 to 5 , concentrations at the end of the cycle decreased progressively to reach $\left[\mathrm{Ca}^{2+}\right] \approx 0.25 \mathrm{mmol} / \mathrm{L}$ and $\left[\mathrm{K}^{+}\right] \approx 0.09 \mathrm{mmol} / \mathrm{L}$ in $\mathrm{N}+\mathrm{OA} 1$ and $\left[\mathrm{Ca}^{2+}\right] \approx 0.22 \mathrm{mmol} / \mathrm{L}$ and $\left[\mathrm{K}^{+}\right] \approx 0.08 \mathrm{mmol} / \mathrm{L}$ in $\mathrm{N}+\mathrm{OA} 2$ at the end of the 5 th leaching cycle.

Concentrations of nitrates in $\mathrm{N}+\mathrm{OA} 1$ and $\mathrm{N}+\mathrm{OA} 2$ (Table 2) remained equivalent to the initial value $(32.3 \mathrm{mM})$. Nitrites were not detected in either solution. Moreover, cations' chromatograms did not reveal any peak due to ammonium $\mathrm{NH}_{4}{ }^{+}$, indicating that no abiotic reduction of nitrate occurred in the conditions of the experiment. 
Concentrations of acetate in $\mathrm{N}+\mathrm{OA} 1$ and $\mathrm{N}+\mathrm{OA} 2$ were almost constant throughout the experiment and were similar to initial concentrations (Table 2). In contrast, the concentration of oxalate, which was initially $0.17 \mathrm{mmol} / \mathrm{L}$, had decreased at the first sampling time $(0.08$ day $\sim 2$ hours) and remained relatively stable (equal to $0.06 \pm 0.01 \mathrm{mmol} / \mathrm{L}$ ) in the following samples.

\subsubsection{Mineralogical changes in the cement pastes}

Fig. 2 presents the mineralogical characterisation by XRD of the CEM V paste specimens at the end of the leaching experiments by N+OA2 solution. Results obtained for the leaching experiment by $\mathrm{N}+\mathrm{OA} 1$ are not shown. Diffractograms are presented according to the distance from the surface in contact with the test solution.

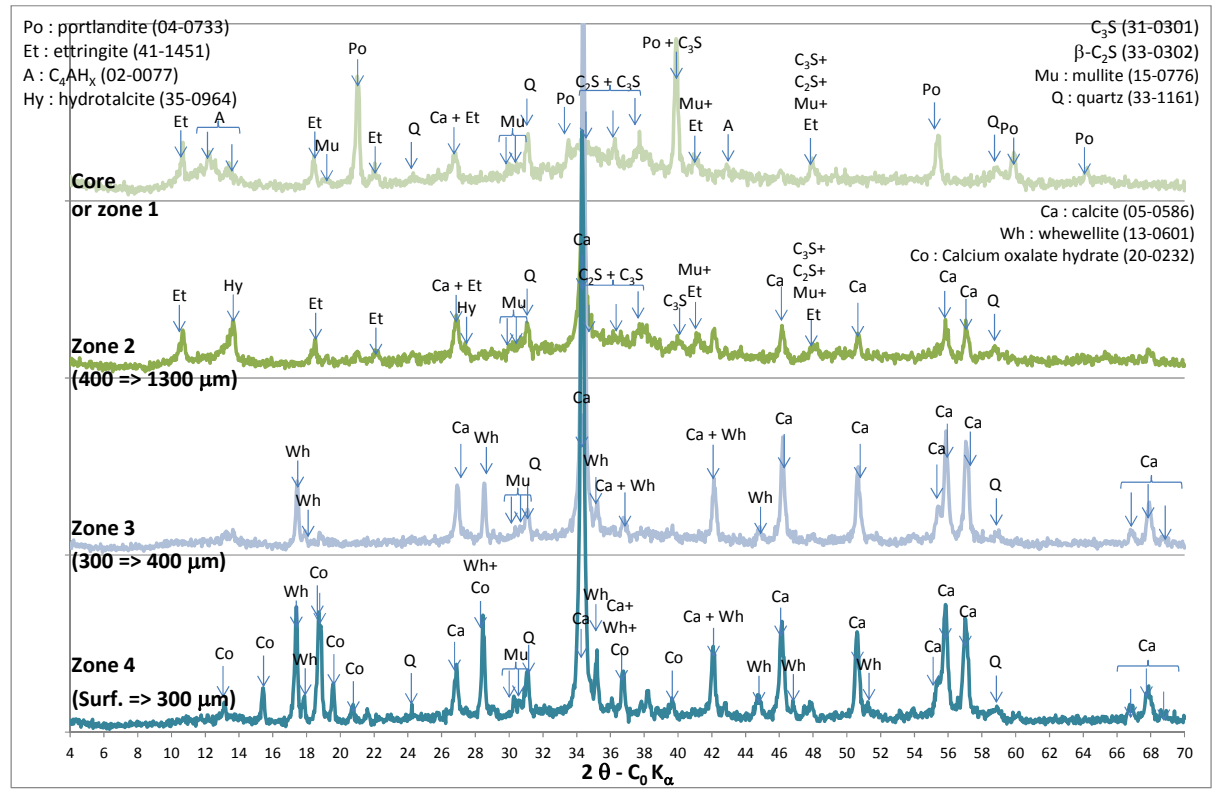

Fig. 2. XRD mineralogical analyses of CEM V paste specimen after 5-day leaching in N+OA2 (acetic 0.33 $\mathrm{mM} /$ oxalic $0.17 \mathrm{mM}$ acids, nitrate) solution for various distances in from the surface of the specimen.

The analyses showed that alterations led to a mineralogical zonation of the specimens.

Diffractograms of control zones ("core or zone 1" on Fig. 1) performed at $5 \mathrm{~mm}$ depth present typical peaks of anhydrous and hydrated cementitious phases and of quartz.

In the peripheral part of cement pastes immersed in $\mathrm{N}+\mathrm{OA} 1$ (acetic acid) solution, all crystallised cementitious phases had disappeared. A thin carbonated layer was observed (the same as for control specimens kept in water). Neither Ca-acetate nor Na-acetate characteristic peaks were found on the diffractogram.

The peripheral zone of the specimen immersed in N+OA2 (acetic/oxalic acids) solution showed 3 zones with different mineralogical characteristics (zones 2 to 4 on Fig. 2) with a thickness of approximately $1.3 \mathrm{~mm}$. All crystallised cementitious phases were progressively dissolved in these zones. In the outer layers (zones 3 and 4), calcite and calcium oxalate mono- and tri-hydrates (or whewellite $\left(\mathrm{CaC}_{2} \mathrm{O}_{4} \cdot \mathrm{H}_{2} \mathrm{O}\right)$ and caoxite $\left.\left(\mathrm{CaC}_{2} \mathrm{O}_{4} \cdot 3 \mathrm{H}_{2} \mathrm{O}\right)\right)$ had precipitated. Neither Ca- or Na-acetate nor Na-oxalate salt peaks were found in the diffractograms.

Precipitation of whewellite in cement paste specimens immersed in oxalic acid solutions $(0.28$ M) has been observed experimentally by Larreur-Cayol et al. [16]. Ca-oxalate tri-hydrate, mentioned by Streit et al. [27] is not very stable [33] and is very easily transformed into di- or mono-hydrate Ca-oxalate [34,35]. Nevertheless, the precipitation of Ca-oxalate tri-hydrate jointly with monohydrate has already been observed [36,37]. 


\subsubsection{Discussion}

Finally, the results of cement paste mineralogical analyses coupled with those of chemical analyses of the solutions showed that the exposure of CEM V paste specimens to N+OA1 solution was similar to a leaching of cement paste by pure water or nitric acid [38-40]. Acetate ion did not combine with cations released by the cementitious matrix. This result is in accordance with those obtained by other authors who have worked on the attack of cementitious matrix by acetic acid but with different concentrations of acids [15,17,32]. Moreover, it should be noted that a numerical analysis by Larreur-Cayol et al. [41] suggested that no Ca-acetate aqueous complex forms in solutions with acetate concentrations ranging from $10^{-5} \mathrm{M}$ to $0.3 \mathrm{M}$. Thus, regarding the frame of the study, the reactions between acetic acid (released by bitumen) and concrete should not modify acetate bioavailability for bacteria that may be present inside the waste repository cells.

In contrast, when oxalic acid was present in solution, reactions of oxalate anion with cementitious cations (calcium at least) occured and led to the formation of various forms of calcium oxalate salts. Precipitation of calcium oxalate salt in oxalic acid solution containing calcium has been confirmed numerically by Larreur-Cayol [42] for a large range of oxalate activity $\left(10^{-5} \mathrm{M}-0.3 \mathrm{M}\right)$. In the present study conducted with oxalic acid concentration of $0.17 \mathrm{mM}, 65 \%$ of oxalate was combined with cementitious cations. Consequently, with respect to biotic studies conducted in the presence of cementitious matrices, oxalate could be less bioavailable to bacteria.

\subsection{Reactivity of nitrates in the presence of steel and under alkaline conditions}

In this section, the results of the experiments of CEM $\mathrm{V}$ paste/steel/bitumen immersion in $\mathrm{N}$ solutions (nitrates alone) are presented and discussed.

\subsubsection{Composition, Eh and $\mathrm{pH}$ of the test solutions}

The increase of $\mathrm{pH}$ of the solution was rapid during the first day (from 7.0 to 10.5-11.0) and then slowed down, reaching 11.3 at the end of the 7-day-experiment. The $\mathrm{pH}$ of the solution was thus rather controlled by the release of $\mathrm{OH}^{-}$ions by the cementitious matrix than by organic compounds possibly released by bitumen. It should be noted that the evolution of $\mathrm{pH}$ was sensibly the same in the presence of bitumen and cementitious matrix with or without steel in the system (results not shown). So, the presence of steel did not seem to influence the $\mathrm{pH}$ of the system.

Redox potential, initially $325 \mathrm{mV}$ (reference electrode $\mathrm{Ag} / \mathrm{AgCl}, \mathrm{E}=199 \mathrm{mV}$ ) which is typical of a water in contact with oxic atmosphere, evolved mainly in the first half day. It first decreased to -25 $\mathrm{mV}$ and then increased to $100 \mathrm{mV}$ before stabilizing around $25 \mathrm{mV}$ until the end of the experiment.

Concentrations of $\mathrm{K}$ and $\mathrm{Ca}$ progressively increased and reached 1.4 and $0.5 \mathrm{mmol} / \mathrm{L}$ at 7 days (Table 3). Concentrations of acetate and oxalate were almost zero (same as cement-bitumen systems without steel, results not shown), indicating that these acids were not released by bitumen during the leaching period. Concentrations of nitrates showed very slight decrease (reduction of about 1.07 $\mathrm{mmol} / \mathrm{L}$ in 7 days $)$, and traces of nitrites $(0.01 \mathrm{mmol} / \mathrm{L})$ were found in the solution from 1 day of experiment (Table 3).

Table 3. Evolution of concentrations $(\mathrm{mmol} / \mathrm{L})$ of cations and anions in $\mathrm{N}$ solutions with time of experiment for the bitumen-steel-cement paste system. <DL: lower than the detection limit.

\begin{tabular}{|c|c|c|c|c|c|c|}
\hline Time (day) & {$\left[\mathbf{K}^{+}\right]$} & {$\left[\mathbf{C a}^{2+}\right]$} & {$[\mathbf{A c}]$} & {$[\mathbf{O x}]$} & {$\left[\mathbf{N O}_{3}{ }^{-}\right]$} & {$\left[\mathbf{N O}_{\mathbf{2}}{ }^{-}\right]$} \\
\hline 0.0 & 0.00 & 0.01 & $<\mathrm{DL}$ & $<\mathrm{DL}$ & 32.10 & $<\mathrm{DL}$ \\
\hline 1.2 & 0.41 & 0.27 & $<\mathrm{DL}$ & $<\mathrm{DL}$ & 31.99 & 0.01 \\
\hline 2.3 & 0.70 & 0.35 & $<\mathrm{DL}$ & $<\mathrm{DL}$ & 31.56 & 0.01 \\
\hline 7.0 & 1.40 & 0.52 & $<\mathrm{DL}$ & $<\mathrm{DL}$ & 31.03 & 0.01 \\
\hline
\end{tabular}


Moreover, chromatograms showed the presence of ammonium $\mathrm{NH}_{4}^{+}$in the solutions. The concentration of this cation increased with time and exceeded $0.55 \mathrm{mmol} / \mathrm{L}(10 \mathrm{mg} / \mathrm{L})$ at 7 days (Fig. $3)$. This concentration was validated using $\mathrm{NH}_{4}{ }^{+}$rapid colorimetric tests.

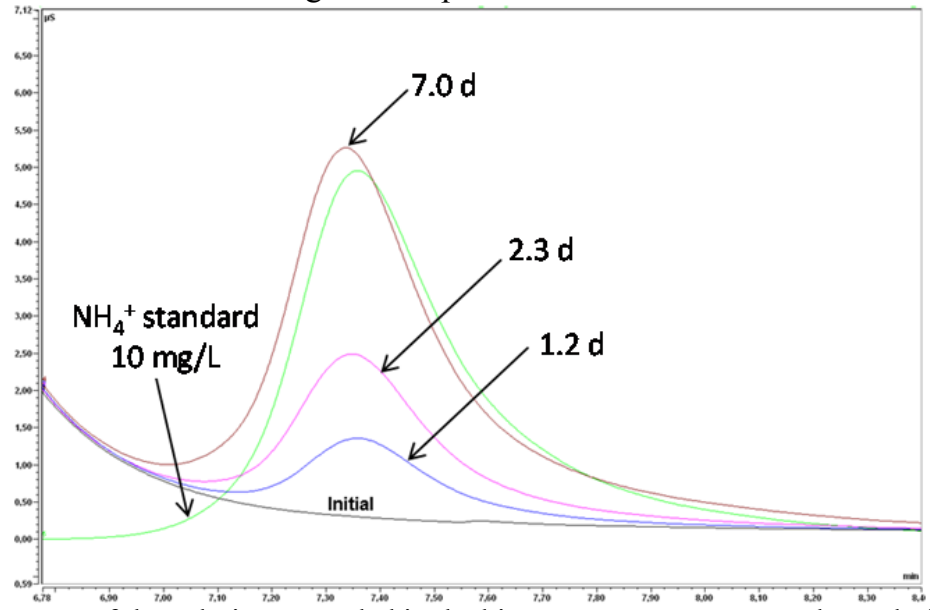

Fig. 3. Chromatograms of the solutions sampled in the bitumen-cement paste-steel-N solution system at the different sampling times.

\subsubsection{Discussion}

Results showed that a small part of nitrates has been reduced to ammonium in the cement pastebitumen-nitrate solution in the presence of carbon steel under anoxic conditions. The reduction of nitrates had not been observed for comparable systems without steel and without (see section 3.1 of this paper) or with bitumen [9]. Steel may act as catalyst in this reaction and/or as electron donor together with $\mathrm{H}_{2}$ probably produced during steel oxidation. Ammonium produced from nitrate reduction has notably been observed by Truche et al. $[7,8]$ in the presence of various types of steel acting as reaction catalysts, but with higher temperature and with or without $\mathrm{H}_{2}$ injection in the systems.

The present study shows that abiotic reduction of nitrates into ammonium catalysed by the presence of carbon steel can occur at low temperature and at alkaline $\mathrm{pH}$ values. Actually, as reported by Fanning [43], the reduction of nitrates in basic solution and in the presence of steel produces ammonia. Some of the ammonia produced is necessarily dissolved in the aqueous solution, leading to the formation of ammonium as observed here. It may be noted that abiotic reduction of nitrates is accompanied with a increase of $\mathrm{pH}\left(\mathrm{H}^{+}\right.$consumption) when the $\mathrm{pH}$ is not buffered [7]. Our experiment showed that the $\mathrm{pH}$ was not disturbed by the presence of steel. It may be supposed that the $\mathrm{pH}$ is controlled by the release of $\mathrm{OH}^{-}$from the cementitious matrix rather than by the consumption of $\mathrm{H}^{+}$because of nitrate reduction.

Finally, the quantity of consumed nitrates $(1.03 \mathrm{mmol} / \mathrm{L})$ was higher than the quantity of nitrites $(0.01 \mathrm{mmol} / \mathrm{L})$ and ammonium produced $(0.55 \mathrm{mmol} / \mathrm{L})$. This may be explained by the fact that all the ammonia produced is not converted into ammonium. Another possibility is that a part of the ammonium produced may have reacted with the cementitious matrix, for example in the way of $\mathrm{Ca}^{2+} \Leftrightarrow \mathrm{NH}_{4}^{+}$exchange reactions, as it is observed during the attack of cementitious matrix by ammonium nitrate [44]. Interactions between ammonium produced by nitrate reduction in the presence of steel and the cementitious matrix will be notably investigated in further studies.

\section{Conclusion}

This study aimed to explore the cementitious matrix-bitumen model leachates-steel interactions in the context of repository of long-lived, intermediate-level, radioactive wastes. Leaching experiments 
were conducted on CEM V paste specimens in contact with aqueous solutions made of nitrates and acetic acid or acetic and oxalic acids (initial pH of 4 and 3.6) with or without steel.

Results showed that an alkaline $\mathrm{pH}(>10)$ is very rapidly (less than 24 hours) established in the aqueous medium. The impact of bitumen model leachates made of acetic acid $(0.50 \mathrm{mM})$ was similar to those found in leaching tests of cementitious matrix as no particular interaction between cementitious cations and acetate anions was observed. In experiments involving bacteria and a cementitious matrix, organic matter (i.e. acetate) would remain in solution and would therefore more probably be available as substrate (both carbon and energy sources) for microorganisms. In contrast, the study conducted with the model leachate made of acetic $(0.33 \mathrm{mM})$ and oxalic $(0.17 \mathrm{mM})$ acids showed a strong interaction between oxalate anions and calcium cations released by the cement paste. $65 \%$ of oxalate was combined with calcium to precipitate as calcium oxalate mono- and trihydrate salts in the periphery of the matrix. Oxalate would thus be less available (than acetate) for bacterial utilisation.

Finally, the study confirmed the stability of nitrates under abiotic conditions in the presence of a cementitious matrix and organic matter without steel. Reduction of nitrates occurred spontaneously in the presence of carbon steel and ammonium was mainly detected as reduction product.

\section{Acknowledgments}

The authors thank Andra (French National Agency for Nuclear Waste Management) for its scientific and financial support.

\section{References}

1. C. Bauer and L. Londe, Rapport Andra (2008).

2. Andra, Dossier 2005 Argile (2005).

3. A. Roulet, Rapport Andra (2004), p. 100 p.

4. I. Walczak, M. Libert, S. Camaro, and J. M. Blanchard, Agronomie 21, 247-257 (2001).

5. A. Albrecht, A. Bertron, and M. Libert, "-in Cement-Based Materials for Nuclear Waste Storage, F. Bart, C. Cau-dit-Coumes, F. Frizon, and S. Lorente, eds., Springer (2012).

6. J. F. Devlin, R. Eedy, and B. J. Butler, J. Contam. Hydrol. 46, 81-97 (2000).

7. L. Truche and G. Berger, Rapport Andra (2010).

8. L. Truche, G. Berger, L. Domergue, and A. Albrecht, Appl. Geochem. 28, 154-163 (2013)(2012).

9. M. Alquier, C. Kassim, B. Erable, A. Bertron, N. Jacquemet, C. Sablayrolles, C. Albasi, R. Basseguy, G. Escadeillas, P. Strehaiano, and M. Vignoles, Rapport Andra (2012), p. 190 p.

10. M. Libert, O. Bildstein, L. Esnault, M. Jullien, and R. Sellier, Phys. Chem. Earth Parts A/B/C 36, 16161623 (2011).

11. M. Libert, I. Pointeau, and R. Sellier, Rapport Andra (2012).

12. M. Alquier, C. Kassim, A. Bertron, N. Jacquemet, C. Sablayrolles, C. Albasi, R. Basseguy, P. Strehaiano, A. Albrecht, and B. Erable, in Proceedings of NUCPERF Workshop on Long-term Performance of Cementitious Barriers and Reinforced Concrete in Nuclear Power Plant and Radioactive Waste Storage and Disposal (2012).

13. A. Bertron, J. Duchesne, and G. Escadeillas, Cem. Concr. Compos. 27, 898-909 (2005).

14. A. Bertron, J. Duchesne, and G. Escadeillas, Cem. Concr. Res. 35, 155-166 (2005).

15. A. Bertron, J. Duchesne, and G. Escadeillas, Mater. Struct. 40, 341-354 (2007).

16. S. Larreur-Cayol, A. Bertron, and G. Escadeillas, Cem. Concr. Res. 41, 882-892 (2011).

17. O. Oueslati and J. Duchesne, Cem. Concr. Res. 42, 205-214 (2012).

18. L. R. Van Loon and Z. Kopajtic, (Nagra, 1990), p. 41.

19. M. Libert and I. Walczak, in ATALANTE 2000 Scientific Research on the Back-end of the Fuel Cycle for the 21th Century (2000), p. 4.

20. S. Nakayama, Y. Iida, T. Nagano, and T. Akimoto, J. Nucl. Sci. Technol. 40, 227-237 (2003).

21. A. Marien, S. Smets, X. Li, and E. Valcke, in Scientific Basis for Nuclear Waste Management Xxxi, W. E. Lee, J. W. Roberts, N. C. Hyatt, and R. W. Grimes, eds. (Materials Research Society, 2008), Vol. 1107, pp. 151-159.

22. I. Walczak, PhD Thesis, INSA Lyon (2000). 
23. A. Kagawa, M. Fukumoto, and K. Kawamura, J. Nucl. Sci. Technol. 37, 934-937 (2000).

24. N. A. Lange and J. A. Dean, Lange's Handbook of chemistry (McGraw-Hill, 1985).

25. A. Bertron and J. Duchesne, in Performance of Cement-based Materials in Aggressive Aqueous Environments, M. Alexander, A. Bertron, and N. De Belie, eds., RILEM State-of-the-Art Reports No. 10 (Springer, 2012), p. 42.

26. A. Seidell, (D. Van Nostrand Company, 1919).

27. J. Streit, L.-C. Tran-Ho, and E. Königsberger, Monatshefte für Chemie / Chemical Monthly 129, 12251236 (1998).

28. J. Sercombe, B. Gwinner, C. Tiffreau, B. Simondi-Teisseire, and F. Adenot, J. Nucl. Mater. 349, 96-106 (2006).

29. B. Gwinner, J. Sercombe, C. Tiffreau, B. Simondi-Teisseire, I. Felines, and F. Adenot, J. Nucl. Mater. 349, 107-118 (2006).

30. A. Bertron, B. Erable, M. Alquier, N. Jacquemet, C. Kassim, C. Sablayrolles, C. Albasi, R. Basseguy, P. Strehaiano, M. Vignoles, A. Albrecht, and G. Escadeillas, Matériaux \& Techniques Soumis, (n.d.).

31. E. Moudilou, PhD Thesis, Université d'Orléans (2000).

32. V. Pavlík, Cem. Concr. Res. 24, 1495-1508 (1994).

33. S. Deganello, A. R. Kampf, and P. B. Moore, Am. Mineral. 66, 859-865 (1981).

34. T. Echigo, M. Kimata, A. Kyono, M. Shimizu, and T. Hatta, Mineral. Mag. 69, 77-88 (2005).

35. B. B. Tomazic and G. H. Nancollas, Invest. Urol. 16, 329-335 (1979).

36. W. Heijnen, W. Jellinghaus, and W. E. Klee, Urol. Res. 13, 281-283 (1985).

37. F. J. Opalko, J. H. Adair, and S. R. Khan, J. Cryst. Growth 181, 410-417 (1997).

38. J. Duchesne and A. Bertron, in Performance of Cement-based Materials in Aggressive Aqueous Environments, M. Alexander, A. Bertron, and N. De Belie, eds., RILEM State-of-the-Art Reports No. 10 (Springer, 2012), p. 22.

39. P. Faucon, P. Le Bescop, F. Adenot, P. Bonville, J. F. Jacquinot, F. Pineau, and B. Felix, Cem. Concr. Res. 26, 1707-1715 (1996).

40. M. Moranville, S. Kamali, and E. Guillon, Cem. Concr. Res. 34, 1569-1578 (2004).

41. S. Larreur-Cayol, L. De Windt, A. Bertron, and G. Escadeillas, in 7th International Symposium on Cement Based Materials for a Sustainable Agriculture (2011), pp. 38-46.

42. S. Larreur-Cayol, PhD Thesis, Université Paul Sabatier, Toulouse III (2012).

43. J. C. Fanning, Coord.Chem.Rev, . 199, 159-179 (2000).

44. G. Escadeillas, in Performance of Cement-based Materials in Aggressive Aqueous Environments, M. Alexander, A. Bertron, and N. De Belie, eds., RILEM State-of-the-Art Reports No. 10 (Springer, 2012), p. 27. 